\title{
The Effect of Addition of Limestone Powder and Fly - Ash on Land Classification
}

\author{
Agata Iwan Candra, Yosef Cahyo SP. Zendy Bima Mahardana \\ Civil Engineering Department, Kadiri University, \\ iwan_candra@unik-kediri.ac.id, yosef_cs@unik-kediri.ac.id, zendymahardana@gmail.com
}

\begin{abstract}
The land is one of the absolute functions in every continuity of the activities of all living things on Earth. The issue of the low soil resilience type of montmorillonite activity indeed remains a problem in construction activities titled construction. Limestone and Fly-Ash is a formulation to change the classification value of montmorillonite soil activity in the following paper compilation research. Soil classification is an effort of the land grouping which is intended to separate the use of land carrying capacity which is more complex for each use of soil structure. The value of the basic soil activity used is 1.3 , obtained from the plastic index calculation of $32.56 \%$ divided by the sieve gradation value is smaller than the sieve number 200 by $25.7 \%$. Thus it shows that the soil structure used for testing is a type of Montmorillonite activity. with the addition of limestone powder additive materials and fly-ash showed activity value const soil structure to be late. In a combination of $5 \%$ additive soil activity type which was previously 1.3 (Montmorillonite classification) to 0.8 (Lilite classification), $10 \%$ additive to 0.7 (Lilite classification), $15 \%$ and $20 \%$ additive to 0.5 or Kaolinite classification.
\end{abstract}

Keywords: Consistency, Gradation, Land Activities.

\begin{tabular}{ccc}
\hline Received & Revised & Published \\
April $11^{\text {th }} 2019$ & ${\text { June } 14^{\text {th }} 2019}^{\text {th }} 2019$ \\
\hline
\end{tabular}

\section{INTRODUCTION}

The land is one of the absolute functions in every continuity of the activities of all living things on Earth. The function of land in the field of Civil Engineering has a very broad function embracing a variety of uses in the facilities and infrastructure to support the activities of all citizens of the earth. These facilities are none other than residential facilities, transportation, economic places, social places and much more. Reporting from previous journals, "Land is the most important component in infrastructure development, because the function of the land itself is as the core foothold of a building", (Candra, 2018)

The issue of the low soil resilience type montmorillonite activity is indeed still a scourge in construction activities titled construction. The following is due to the physical properties of expansive soils or montmorillonite which have a low consistency value. "Expansive soils are problematic soils that have low strength and high shrinkage potential due to changes in soil water content", (A 'la, Setiawan, \& Djarwanti, 2017). "Expansive or swelling soil is a highly plastic soil that normally contains montmorillonite and other active clay minerals", (FAEZEHOSSADAT \& JEFF, 2016). "Plastic clays termed as expansive soils or active soils exhibit volume change when subjected to moisture variations", (Thesis, 2008). With the following problems, it is necessary to make efforts to change the physical according to the classification of the land to stabilize the carrying capacity of the land which is more complex to each development need. 
Limestone and Fly-Ash is a formulation to change the classification value of montmorillonite soil in the following paper compilation research. Where, "lime (limestone) is a sedimentary rock which is mainly composed of calcium carbonate (CaCO3)", (Zaenuri, 2018). and FlyAsh itself is, "general terminology for mild fly ash arising from a combustion process of a material which normally produces ash", (Siswanto, 2019). The following limestone powder will be used as a media to bind the soil structure layer according to its function to be added Fly-Ash grains as a stabilizing media of soil mechanical properties on the effect of the classification value, so that it can be used as a reference in the desirability of soil classification in each addition of the material. With the point of the problem and there is still widespread soil stabilization material, it encourages the author to conduct an experiment that will be compiled into a paper entitled The Effect Of Addition Of Limestone Powder And Fly Ash On Land Classification

\section{LITERATURE REVIE}

\subsection{Montmorillonite Land}

Montmorillonite soil is a material mechanical property of a soil structure that has a special characteristic value following the classification established by E. Bowless guidelines. According to related research, "Montmorillonite, also called smectite, is a mineral formed by two silica sheets and one aluminum sheet (gibbsite)",(Abdurrozak et al., 2017). With mechanical properties, "Soil containing montmorillonite is very easy to expand by adding water content, which furthermore the development pressure can damage light structures", (Widhiarto, Andriawan, Matulessy, Teknik, \& Psikologi, 2015). By thus be concluded that the soil particles montmorillonite has a low consistency value and need the holding of a plan for stabilization.

Reference from the previous testing states that, "the physical and mechanical properties of expansive soils get better with the addition of white soil with a maximum amount of $2.5 \%$ of the dry weight of the soil", (Wardani, Muhrozi, Setiaji, \& Riwu, 2018). The conclusion from the following understanding is a step to improve soil classification value can be done by combining or mixing some organic additives, which in the following studies use a combination of Limestone and Fly-ash.

\subsection{Limestone Powder}

The important role of limestone in the planning of soil stability according to (Tjokrodimuljo,1992), "as a non-brittle material, easy and fast hardening, good workability and good binding capacity", (Study, Sipil, Teknik, \& Kadiri, n.d.). because of its chemical basis, "Limestone contains $98.9 \%$ calcium carbonate $(\mathrm{CaCO})$ and $0.95 \%$ magnesium carbonate (MgCO3)", (Zaenuri, 2018). "Compacted soils have reduced available water capacity", (Ogbeche, 2018). 


\subsection{Fly-Ash}

Fly ash or commonly called rock ash or Matos is an additive material in the following soil stabilization plan research. According to the expert, "Matos is a fine powder consisting of the mineral composition of the additive inorganic serves to strengthen and stabilize the soil physical and chemical", (Kuat, Dan, \& Tanah, 2018). With the following understanding, the use of fly-ash in improving soil stabilization is necessary.

\subsection{Water}

The definition of water is, "Chemical substances with the formula $\mathrm{H} 2 \mathrm{O}$ chemical elements", (Beton Mengunakan, Lumajang, Penambahan, Ridwan, \& Chandra, 2018). And basically, "This chemical is a solvent", (Utami, 2018). The water in the following research is used as a solvent media for test specimens and taken from clean water channels at the Kadiri University Civil Engineering Laboratory.

\subsection{Land Classification}

Soil classification is an effort of the land grouping which is intended to separate the use of land carrying capacity which is more complex for each use of soil structure. "Soil classification is a system of regulating several different types of soil but has similar characteristics into groups and subgroups based on their use", (Susanto, 2009).

TABLE 2.1 CLASSIFICATION OF SOIL

\begin{tabular}{|c|c|}
\hline MINERAL & ACTIVITY VALUES \\
\hline MONTMORILLONITE & $0-7$ \\
\hline LILITE & $0,5-1$ \\
\hline KAOLINITE & 0,5 \\
\hline HALLOSITE & 0,5 \\
\hline ATTAPULGITE & $0,5-1,2$ \\
\hline AILOPHANE & $0,5-1,2$ \\
\hline
\end{tabular}

SOURCE: "BRADJA M. DAS, LAND COMPOSITION PAGE 18”, (Das Braja M, 1988).

In application of an sorting to the classification of the soil, carried out research on the basic effect of any variation of specimens in the following research using a combination of powder material limestone and fly-ash with a percentage of $0 \%$ (testing native land), $5 \%$, $10 \%, 15 \%$ and $20 \%$, using a soil grading and consistency test (plastic index). The formulation that will be used is the following formula :

find the classification of soil minerals $=\quad \frac{\text { soil gradation } 200(\text { micro })}{\text { index plastic }} \times 100 \%$ 


\subsubsection{Soil Gradation Test}

The purpose of the soil grading test is to find out the constituent particles of the soil structure which will be grouped by each soil structure particle to be classified based on the soil consistency test value.

\subsection{Soil Consistency Test}

Soil consistency testing is carried out to determine the water content of soil in a liquid boundary state and the maximum plastic level. The soil consistency test grouping is Liquid limit and Plastic limit test so finding the Plastic Index value, regarding the calculation :

Plastic Index ( IP ) = Liquid Limit ( LL ) - Plastic Limit ( PL ), (Das Braja M, 1988).

\section{METHODS}

3.1 SOIL CLASSIFICATION TEST

3.1.1 SOIL GRADATION TEST

"First the soil sample is encircled, then all the lumps are broken up into smaller particles and then sieved in laboratory experiments. After enough time to sift by vibration, the mass of the soil held at each sieve is weighed. To analyze cohesive soils", (Das Braja M, 1988).

Make gra tie sieving the ground a number of $1000 \mathrm{~g}$ using gr Adasi sieve with a diameter of $>256.64,4,2,1,0.5,0: 25,0.125,0.0625,0.002$, < $0002 \mathrm{~mm}$ and specify the percentage value to sieve gradation reading.

\subsubsection{SOIL CONSISTENCY TEST}

This test is a combination of the liquid limit calculation value with the plastic limit to get the Plastic Index value which is known to test as follows :

\section{A. Liquid limit}

montmorillonite type soil pastes with variations in the combination of lime powder and fly-ash amounting to $0 \%, 5 \%, 10 \%, 15 \%$ and $20 \%$ of the total weight of the test specimens were placed in a brass bowl. "Scratch right in the middle by using standard scrapers. By running the rotator, the bowl is then raised from the height of 0.3937 in $(10 \mathrm{~mm})$. Water content, expressed in terms of ponds, from the soil needed to cover a scratch that is $0.5 \mathrm{in}$. $(12.7 \mathrm{~mm})$ uninteresting basis soil samples in da lam bowl are already 25 punches definition like liquid limit (liquid limit)", (Das Braja M, 1988).

\section{B. Plastic Limit}

Find the plasticity level value of each montmorillonite soil test object with variations in the combination of limestone and fly ash totaling $0 \%, 5 \%, 10 \%, 15 \%$ and $20 \%$ of the total weight of the test specimen. The stages are by grinding the specimens on flat and smooth glass plates until they reach a diameter of $3 \mathrm{~mm}$. 


\section{RESULTS AND DISCUSSION}

\subsection{TREE GRADATION TEST}

From the sieve gradation test from $1000 \mathrm{gr}$ the soil test object type montmorillonite activity found the following results:

TABLE 4.1 GRADATION ANALYSIS OF ORIGINAL SOIL STRUCTURE

\begin{tabular}{|c|c|c|c|}
\hline \multirow{2}{*}{ No } & GRADATION $(\mathrm{mm})$ & $(\mathrm{gr})$ & $(\%)$ \\
\cline { 2 - 2 } & $>256$ & & \\
\hline 1 & $64-256$ & 0 & 0 \\
\hline 2 & $4-6$ & & \\
\hline 3 & $2-4$ & & 0,3 \\
\hline 4 & $1-2$ & 3 & 2,9 \\
\hline 5 & $0,5-1$ & 29 & 4 \\
\hline 6 & $0,25-0,5$ & 40 & 5,1 \\
\hline 7 & $0,125-0,25$ & 51 & 7,4 \\
\hline 8 & $0,0625-0,125$ & 74 & 54,6 \\
\hline 9 & $0,002-0,0624$ & 546 & 25,7 \\
\hline 10 & $<0,002(M I C R O)$ & 257 & 100 \\
\hline 11 & TOTAL & 1000 & \\
\hline
\end{tabular}

SOURCE : TESTING GRADATION OF ORIGINAL SOIL STRUCTURE

\subsection{CONSISTENCY TEST}

The results of testing the soil consistency value to find the Plastic Index value after a combination of materials found the following results :

TABLE 4.2 LIMIT - CONSISTENCY OF SOIL COMBINATION VALUE WITH LIMESTONE AND FLY-ASH POWDER

\begin{tabular}{|c|c|c|c|}
\hline $\begin{array}{c}\text { LIMESTONE POWDER AND FLY } \\
\text { ASH } \\
(\%)\end{array}$ & $\begin{array}{c}\text { LIQUID LIMIT } \\
(\%)\end{array}$ & $\begin{array}{c}\text { PLASTIC LIMIT } \\
(\%)\end{array}$ & $\begin{array}{c}\text { INDEX PLASTIC } \\
(\%)\end{array}$ \\
\hline 0 & 257 & 25,7 & 32,56 \\
5 & 257 & 25,7 & 21,78 \\
10 & 257 & 25,7 & 19,25 \\
15 & 257 & 25,7 & 12,08 \\
20 & 257 & 25,7 & 11,36 \\
\hline
\end{tabular}


SOURCE : TEST BORDER CONSISTENCY OF SOIL COMBINATION VALUE WITH LIMESTONE AND FLY POWDER - ASH

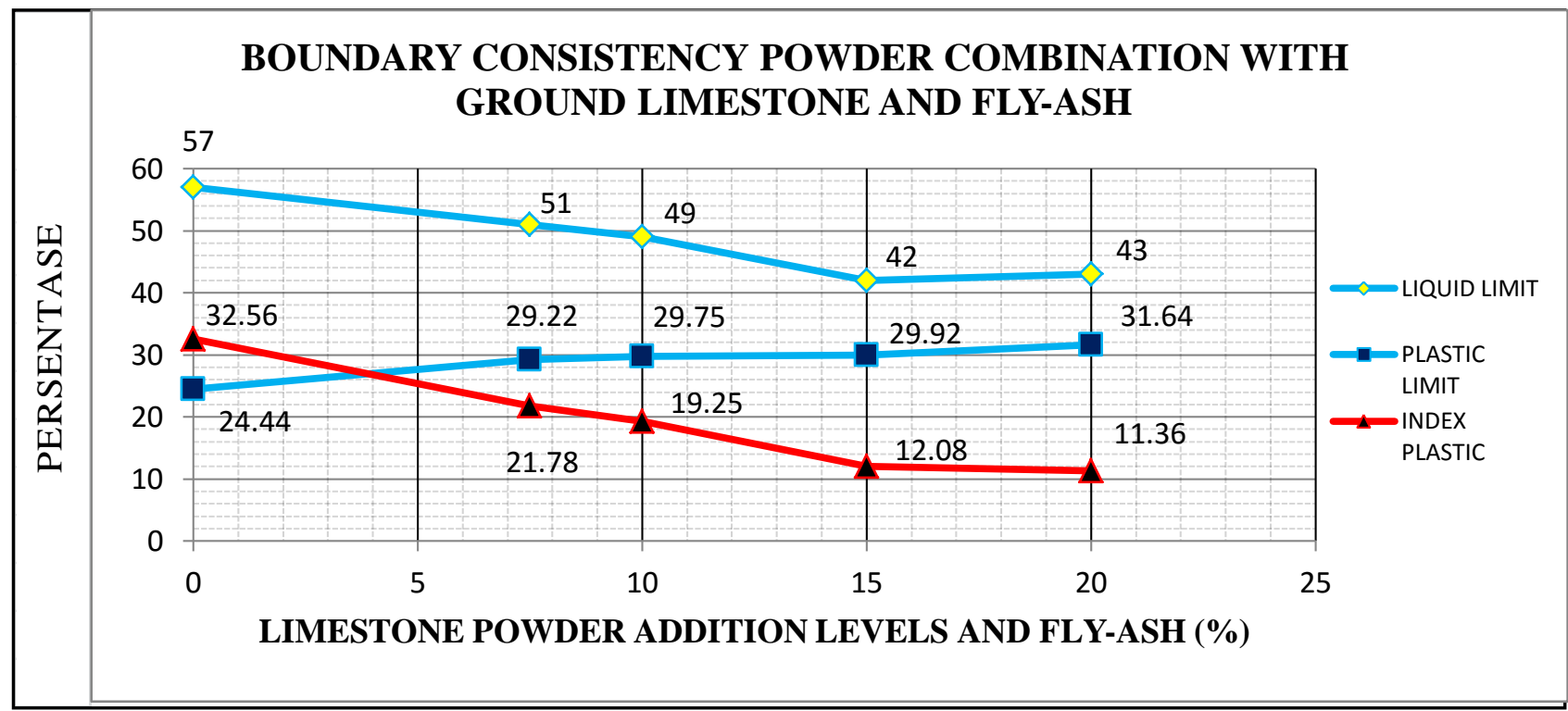

SOURCE : LIMITS OF CONSISTENCY OF SOIL COMBINATION TEST VALUE WITH LIMESTONE AND FLY - ASH POWDER

FIGURE 4.1 GRAPHICS OF CONSISTENCY TEST RESULTS ON TEST OBJECTS

\subsection{CLASSIFICATION CALCULATION RESULTS}

From the results of the original soil gradation test and also the soil consistency test, the results can be summarized in the following table 4.3 :

TABLE 4.3 CLASSIFICATION OF SOIL AFTER THE COMBINATION OF LIMESTONE AND FLY-ASH POWDER MATERIALS

\begin{tabular}{|c|c|c|c|c|c|}
\hline \multirow{2}{*}{$\begin{array}{c}\text { PERCENTAGE } \\
\text { LIMESTONE POWDER } \\
\text { AND FLY-ASH (\%) }\end{array}$} & \multicolumn{2}{|c|}{$\begin{array}{c}\text { MATERIALIS GRADATION } \\
>0,02\end{array}$} & \multirow{2}{*}{ IPICRO) } & \multirow{2}{*}{ ACTIVITY } & \multirow{2}{*}{ CLASSIFICATION } \\
\cline { 2 - 4 } & $(\mathrm{gr})$ & $(\%)$ & & & \\
\hline 0 & 257 & 25,7 & 32,56 & 1,3 & Montmorillonite \\
5 & 257 & 25,7 & 21,78 & 0,8 & Lilite \\
10 & 257 & 25,7 & 19,25 & 0,7 & Lilite \\
15 & 257 & 25,7 & 12,08 & 0,5 & Kaolinite \\
20 & 257 & 25,7 & 11,36 & 0,5 & Kaolinite \\
\hline
\end{tabular}

with the addition of additive powder Limestone and Fly-Ash as a media changer combination of soil, classification showed a significant change. Thus it can be concluded that in this study limestone powder and fly- sh are very influential on soil classification which is indicated by a change in the value of soil activity. 


\section{CONCLUSION}

On the results of the test specimens from the preparation of the following paper entitled THE EFFECT OF ADDITION OF LIMESTONE POWDER AND FLY - ASH TOWARDS CLASSIFICATION OF SOIL, there are conclusions as follows :

1. The value of the basic soil activity used is 1.3 obtained from the calculation of the plastic index of 32.56 divided by a sieve gradation value is smaller than the sieve number 200 of 25. 7. Thus it shows that the original soil used has a type of Montmorillonite activity value.

2. On the addition of $5 \%$ additive type of soil activity previously 1.3 (montmorillonite) becomes 0. 8 (Lilite), 10\% additive to 0.7 (Lilite), 15\% and 20\% additive to 0.5 or classified kaolinite. With the addition of limestone powder additive materials and fly-ash show changes in the value of the activity of soil structure to be constant.

\section{ACKNOWLEDGMENTS}

Thank you the amount of the authors say to the University of Kadiri, especially to the Chancellor of the University of Kadiri Ir. Djoko Rahardjo, MP. Who has provided full support in the form of grant funds used as research material in the preparation of the following paper.

\section{REFERENCES}

A 'la, H., Setiawan, B., \& Djarwanti, N. (2017). Penambahan Limbah Plastik Pada Tanah Ekspansif, (36), 1170-1178.

Abdurrozak, M. R., Mufti, D. N., Studi, P., Sipil, T., Islam, U., Studi, P., ... Islam, U. (2017). STABILISASI TANAH LEMPUNG DENGAN BAHAN TAMBAH ABU SEKAM, XXII(2), 416-424.

Beton Mengunakan, J., Lumajang, P., Penambahan, D., Ridwan, A., \& Chandra, A. (2018). Additive Masterpozzolith ® 402R, 3(2), 192-197.

Candra, A. I. (2018). STUDI KASUS STABILITAS STRUKTUR TANAH LEMPUNG PADA JALAN TOTOK KEROT KEDIRI MENGGUNAKAN LIMBAH KERTAS. UKaRsT, 2(2), 11. https://doi.org/10.30737/ukarst.v2i2.255

Das Braja M. (1988). Mekanika Tanah (Prinsip-Prinsip Rekayasa Geoteknis) Jilid 1 (Vol. 1). Erlangga. Retrieved from https://kupdf.net/download/mekanika-tanah-jilid-2-braja-mdas_59b0f4cfdc0d607660568edb_pdf

FAEZEHOSSADAT, K., \& JEFF, B. (2016). Expansive Soil: Causes and Treatments. I-Manager's Journal on Civil Engineering, 6(3), 1. https://doi.org/10.26634/jce.6.3.8083

Kuat, T., Dan, G., \& Tanah, K. (2018). PENGARUH STABILISASI TANAH MENGGUNAKAN KAPUR DAN MATOS TERHADAP KUAT GESER DAN KONSOLIDASI TANAH GAMBUT Aris Prabowo 1, Miftahul Fauziah, S.T., M.T., Ph.D. 1.

Ogbeche, S. (2018). Overview of Engineering Problems of Soil Compaction and Their Effects on 
Growth and Yields of Crops Overview of Engineering Problems of Soil Compaction and Their Effects on Growth and Yields of Crops. European Journal of Advances in Enineering and Technology, 5(9), 701-709.

Siswanto, E. (2019). Penambahan Fly Ash Dan Serat Serabut Kelapa Sebagai Bahan Pembuatan Beton. UKaRsT, 3(1), 48. https://doi.org/10.30737/ukarst.v3i1.352

Study, P., Sipil, T., Teknik, F., \& Kadiri, U. (n.d.). Stabilisasi struktur tanah lempung dengan menggunakan bahan tambahan abu sekam padi dan kapur pada subgrade perkerasan jalan sudjati, 1-9.

Susanto, A. (2009). PENGARUH STABILISASI TANAH LEMPUNG DENGAN ASPAL EMULSI Klasifikasi tanah, 3(KoNTekS 3), 6-7.

Thesis, D. (2008). Geotechnical Aspects of Buildings on Expansive Soils in Kibaha , Tanzania. Buildings. Retrieved from http://www.diva-portal.org/smash/get/diva2:10579/FULLTEXT01.pdf Utami, S. (2018). Ketersediaan Air Bersih Untuk Kesehatan. Optimalisasi Peran Sains Dan Teknologi Untuk Mewujudkan Smart City, (June). Retrieved from https://www.researchgate.net/profile/sri_utami29/publication/326057942

Wardani, S. P. R., Muhrozi, M., Setiaji, A. R. A., \& Riwu, D. R. (2018). Stabilisasi Tanah Ekspansive dengan Menggunakan Tanah Putih untuk Tanah Dasar di Daerah Godong Kabupaten Grobogan Jawa Tengah. Media Komunikasi Teknik Sipil, 24(1), 1. https://doi.org/10.14710/mkts.v24i1.16275

Widhiarto, H., Andriawan, A. H., Matulessy, A., Teknik, F., \& Psikologi, F. (2015). STABILISASI TANAH LEMPUNG EKSPANSIF DENGAN MENGGUNAKAN CAMPURAN ABU-SEKAM DAN KAPUR, 01(02), 135-140.

Zaenuri, M. (2018). Penelitian Penggunaan Batu Gamping Sebagai Agregat Kasar Dan Filler Pada Aspal Campuran. UKaRsT, 2(1). https://doi.org/10.30737/ukarst.v2i1.357. 